\title{
What is the best way to organize vaccination services for the children of Quebec, Canada?
}

\author{
Maryse Guav ${ }^{1,2^{*}}$, Paule Clément ${ }^{2}$, Carole Vanier ${ }^{1}$, Sandie Briand ${ }^{2}$, Cécile Michaud ${ }^{1,3}$, Chantal Boulet ${ }^{4}$, \\ Joane Désilets ${ }^{5}$, Fernand Guillemette ${ }^{6}$, Eve Dubé ${ }^{1,7}$, Nicole Boulianne ${ }^{1,7}$, Jacques Lemaire ${ }^{2}$, Monique Landry ${ }^{8}$, \\ Geneviève Baron ${ }^{1,9}$
}

From Health Services Research: Evidence-based practice

London, UK. 1-3 July 2014

\section{Background}

Recently in Quebec, Canada, several contextual elements (e.g. physician disengagement, delayed appointments and late vaccines) justified a review of how child vaccination services are offered. A 5-year study begun in 2010-2011 aims to identify the optimal organizational model(s) for vaccination services for children aged 0-5 years. The first three year process and progress are reported.

\section{Materials and methods}

This action research project adopts the Appreciative Inquiry methodology [1], using case studies [2]: 3 regions are currently studied (region 1: 16,000 births/year; region 2: 5,000 births/year; region 3:5,000 births/year). Building the model began with the development of a conceptual model drawn from a literature review. The participatory process relies on a steering committee for each case study, made up of players from local and regional levels and researchers. It meets monthly to discuss, reflect on and review vaccination service components. Various facilitation techniques foster the gradual production of an array of documents (e.g. accounts, schemas, tables) to fuel the discussion. Logbooks and field notes document the process. Qualitative analyses have been done.

\section{Results}

To date, charts of service usage and schemas illustrating current vaccination service organization have been developed. The appointment-making processes, the functioning of vaccination clinics, the management of immunizing products and vaccination data have been described. Some courses of action have emerged and will be further explored: simplified appointment making, more systematic reminders and follow-ups, better structured vaccine transport and storage.

\section{Conclusion}

Thanks to the approach used, emerging solutions will be more sustainable, acceptable and adapted to needs. Identification of the optimal model(s) for the organization of child vaccination services, adjusted to the various contexts is on progress.

\section{Authors' details \\ 'University of Sherbrooke, Longueuil, Quebec, Canada. ${ }^{2}$ National Institute of Public Health, Montreal, Quebec, Canada. ${ }^{3}$ Charles LeMoyne Hospital Research Centre, Longueuil, Quebec, Canada. ${ }^{4}$ Public Health Directorate, Agence de la sante et des services sociaux de la Montérégie, Longueuil, Quebec, Canada. ${ }^{5}$ Public Health Directorate, Agence de la sante et des services sociaux de Lanaudière, Joliette, Quebec, Canada. ${ }^{6}$ Public Health Directorate, Agence de la sante et des services sociaux de la Mauricie et du Centre-du-Québec, Trois-Rivières, Quebec, Canada. ${ }^{7}$ Centre de recherche du $\mathrm{CHU}$ de Quebec, Quebec, Canada. ${ }^{8}$ Quebec Ministry of Health, Montreal, Quebec, Canada. ${ }^{9}$ Public Health Directorate, Agence de la santé et des services sociaux de l'Estrie, Sherbrooke, Quebec, Canada.}

Published: 7 July 2014

References

1. Reed J: Appreciative Inquiry: Research for Change. Thousand Oaks: Sage Publications; 2007.

2. Yin R: Case study research: design and methods-Fourth Edition. Thousand Oaks: Sage Publications; 2009.

doi:10.1186/1472-6963-14-S2-P52

Cite this article as: Guav et al:: What is the best way to organize vaccination services for the children of Quebec, Canada? BMC Health Services Research 2014 14(Suppl 2):P52.

${ }^{1}$ University of Sherbrooke, Longueuil, Quebec, Canada

Full list of author information is available at the end of the article

(c) 2014 Guav et al; licensee BioMed Central Ltd. This is an Open Access article distributed under the terms of the Creative Commons Attribution License (http://creativecommons.org/licenses/by/4.0), which permits unrestricted use, distribution, and reproduction in any medium, provided the original work is properly cited. The Creative Commons Public Domain Dedication waiver (http:// creativecommons.org/publicdomain/zero/1.0/) applies to the data made available in this article, unless otherwise stated. 